\title{
Push-Pull Factors of Migration Today in Albania
}

\author{
Roland Sahatcija \\ Department of Informatics and Research Science, \\ Mediterranean University of Albania, Albania \\ Corresponding Author \\ Anxhela Ferhataj \\ Department of Informatics and Technology, \\ European University of Albania, Albania \\ Ariel Ora \\ Researcher, Canada
}

\begin{abstract}
Migration is a phenomenon that has significantly impacted Albanian society. In recent years, migration has increased noticeably in Albania. The majority of departures consists of students and university educated persons. This study will research the factors influencing the perceptions and decision-making of migrating students. The objective of this research paper corresponds with the study of the correlation between push-pull factors of student perceptions on migration and of making the decision to migrate. This study will employ quantitative research. The study sample comprises 163 Mediterranean University of Albania students. Research hypotheses are tested with a 95\% confidence interval. Push factors influence student perceptions to migrate, just as economic standing, conflict, unemployment and discrimination influence the students' decision to migrate. Whereas, personal safety is not significantly correlated to migratory decision-making. Pull factors do not influence the perceptions of migration of students. Whereas, career opportunities, improving the quality of life and the quality of education influence in student decisions to migrate.
\end{abstract}

Keywords: migration, push factors, pull factors, students

\section{Introduction}

People migrate to other countries in search of better opportunities. Different people have different reasons to migrate, however everyone is in search of a better life in the host country. The migration phenomenon can also have a negative impact on society, such as the flight of human capital in large numbers. According to some researchers (Semiv \& Semiv, 2010; Kumpikaite \& Zickute, 2012) migration can have a negative impact on the social and economic development of a country, as well as on other aspects. Simultaneously, as a result of research (Gibson \& David, 2011; Hawthorne, 


\section{Journal of International Cooperation and Development \\ www.richtmann.org/journal \\ Vol 3, No 1, May 2020}

2010) it is confirmed that it can also manifest certain benefits, such as: promoting the country abroad, learning and training, research exchange and networking, cultural exchange, professional development, information exchange, etc. The admission of highly qualified and expert persons can be beneficial to the host country. Most countries in the world give close and thoughtful attention to their migration policies. They continuously seek to attract professionals, specialists, researchers and students, particularly high performing ones. This paper focuses on students. The objective of this scientific paper relates to the study of the link which exists between push-pull factors in the perception of students regarding migration and migration decision-making.

\section{Literature Review}

A field of interest for researchers (Ferriss, 1965; McGill, 2013; Ramirez \& Kumpikaite, 2013 ) is student migration. This being closely connected to the fact that students are the hope and future of a nation, therefore the effects of their migration not only have an impact on the present but also the future of a country. Different countries have welldeveloped migration policies for recruiting and retaining doctoral students. Some of the methods applied are: supplying funding, paying for their studies on condition that they return to work for a given period of time in their country, etc (Saxenian, 2005). The return of students in their country of origin has a positive impact on society. Several researchers have concluded that their contribution in their country of origin is high. (Hawthorne, 2010; Saxenian, 2005). The knowledge, information, and skills that they have obtained in the host countries can be applied in the country of origin. Thus, once having returned they begin implementing their knowledge. It is important to understand the number of migrating students and the number of returning students. If the number of returning students is higher than the number of departing students, it shows that a country has the capability of retaining students and attracting them from other countries. However, if the opposite phenomenon takes place, it is necessary for such country to focus on its migration policies and the development of pertinent policies in order to reclaim the students who are away.

According to Kerri (1976) the factors influencing the decision-making to migrate are separated in push and pull factors. The push factors are the factors that cause people to leave a country. Whereas, pull factors are defined as the factors which cause people to move to a certain area. From the research (Hazen \& C. Alberts, 2006) it has been concluded that social and personal factors have influenced students' decision-making to return to their country of origin. However, some students remain in the country where they have migrated. Their decision to stay is influenced by economic and professional factors. (Hazen \& C. Alberts, 2006).

The factors which influence the decision to migrate are different. According to Czaika (2015) economic status plays a primary role in the decision to migrate. Persons 


\section{Journal of International Cooperation and Development \\ www.richtmann.org/journal \\ Vol 3, No 1, May 2020}

living in unfavourable economic conditions tend to migrate, while those in a prosperous economic state prefer to stay in their country. Therefore, people tend to migrate to improve their economic condition (Žičkutè \& Kumpikaite, 2015). At the same time, there are individuals who migrate in search of better job opportunities and career advancement (Czaika \& Vothknecht, 2014). According to studies (Tupa \& Strunz, 2013) social, psychological and biological factors influence migration decision-making. Polgreen and Simpson (2011) concluded that happiness is an influencing factor in migration. Based on its U-shaped distribution, researchers assert that people coming from "happy" and "unhappy" countries are most prone to migrate compared to people from countries of average happiness. Meanwhile, the data from Albania show that the reasons for migration are unemployment and better employment opportunities. Whereas, the reasons for returning are losing one's job and the family (Filipi, Galanxhi, Nesturi, \& Grazhdani, 2013).

The research questions of this study are:

1. What are the attitudes of students toward migration?

2. What is biggest challenge for students if they would migrate in the future?

The research hypotheses of this study are:

- H1a: Push factors influence student decision-making in migrating $(\alpha=0.05)$.

- H1b: Push factors influence student perception in migrating $(\alpha=0.05)$.

- H2a: Pull factors influence student decision-making in migrating $(\alpha=0.05)$.

- H2b: Pull factors influence student perception in migrating ( $\alpha=0.05)$.

The literature review leads to this conceptual model:

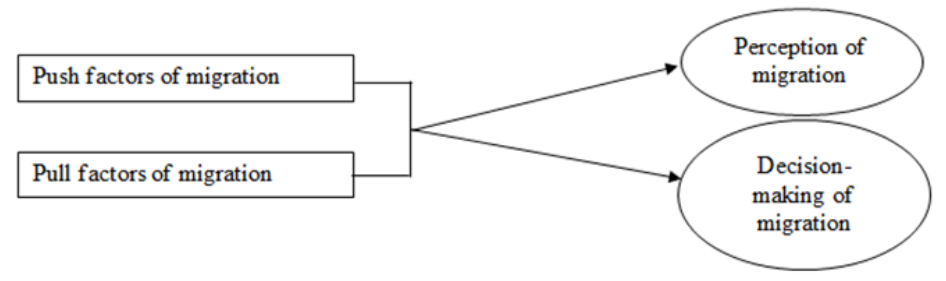

\section{Methodology}

This study utilizes qualitative research. The research instrument is the questionnaire, which has been adapted to the particulars of this study (Hazen \& C. Alberts, 2006). The questionnaire was distributed online, during the academic year 2017-2018. The questionnaire consists of 27 questions. The first and last parts consist of alternative questions, while for the questions of the second part a 5-point Likert scale is used, ranging from "Not at all important" to "Extremely important". 163 students from the Mediterranean University of Albania participated in this study. There are 145 valid questionnaires. The response rate of return is approximately $89 \%$. The characteristics of the study sample are shown in the following graphs: 


\section{Journal of International Cooperation and Development \\ www.richtmann.org/journal}

Vol 3, No 1, May 2020
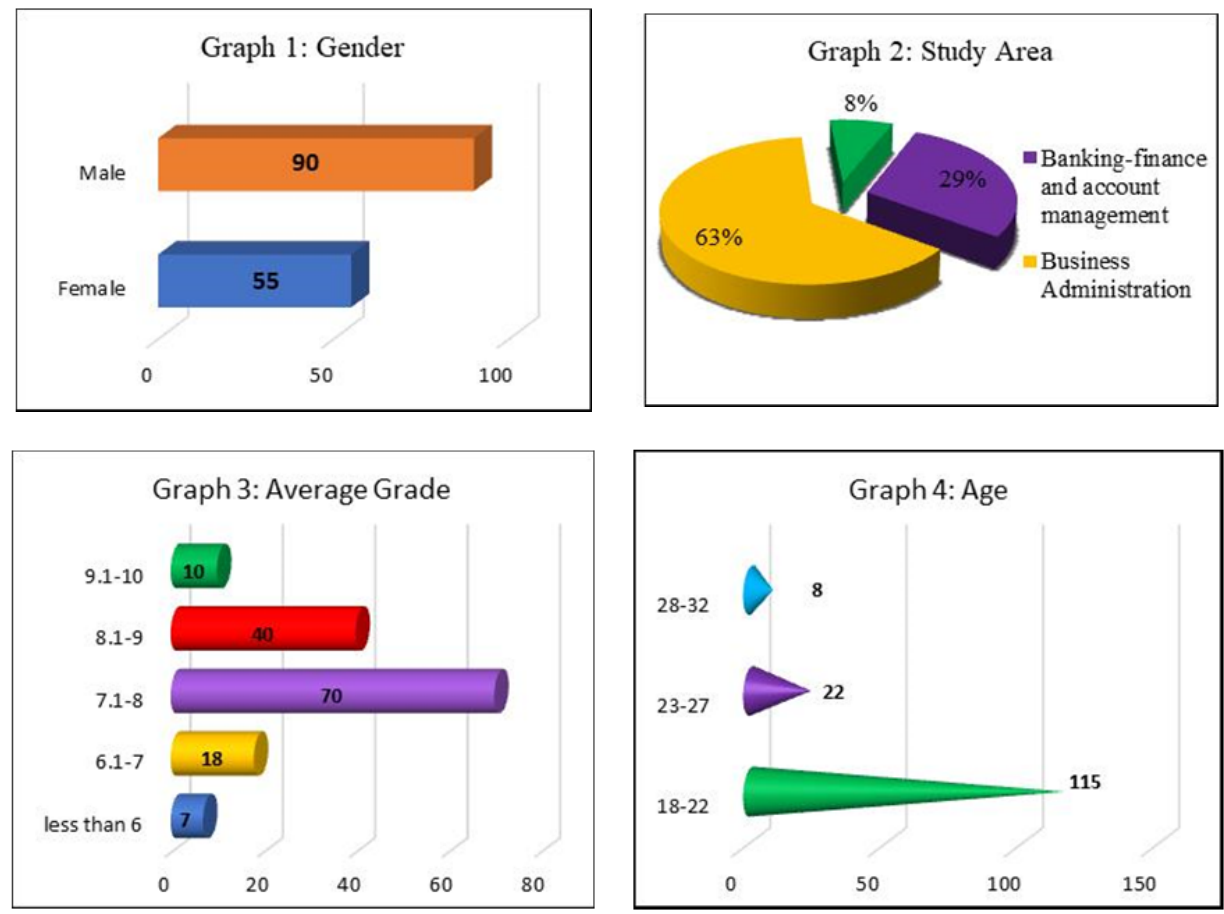

Data analysis was conducted with SPSS 20 and JASP-0.8.5.1. The reliability coefficient Cronbach's $\alpha$ in this questionnaire is 0.952 (Table 1). A value larger than 0.7 shows that the data are valid and reliable for the purposes of this study.

Table 1: Reliability coefficient

\begin{tabular}{cc}
\hline & Cronbach's $\boldsymbol{\alpha}$ \\
\hline scale & 0.952 \\
\hline
\end{tabular}

Note. Of the observations, 145 were used, 0 were excluded listwise, and 145 were provided.

\section{Empirical Analysis}

\subsection{What are the attitudes of student toward migration?}

The largest part of students think that people ought to migrate to other countries. Only 24 students assert that people must remain in the country of origin (Table 2). If students were in charge of migration policy-making, 56 students would create policies for reducing the phenomenon of migration, 61 would create encouraging policies in favour of migration and 28 are undecided (Table 3 ). 


\section{Journal of International Cooperation and Development}

www.richtmann.org/journal

Vol 3, No 1, May 2020

Table 2: Migration toward other countries

\begin{tabular}{lcccc}
\hline & Frequency & Percent & Valid Percent & Cumulative Percent \\
\hline Yes & 121 & 83.4 & 83.4 & 83.4 \\
No & 24 & 16.6 & 16.6 & 100.0 \\
Missing & 0 & 0.0 & & \\
Total & 145 & 100.0 & & \\
\hline
\end{tabular}

Table 3: Migration policy

\begin{tabular}{lcccc}
\hline & Frequency & Percent & Valid Percent & Cumulative Percent \\
\hline Would reduce migration & 56 & 38.6 & 38.6 & 38.6 \\
Would encourage migration & 61 & 42.1 & 42.1 & 80.7 \\
Does not know & 28 & 19.3 & 19.3 & 100.0 \\
Missing & 0 & 0.0 & & \\
Total & 145 & 100.0 & & \\
\hline
\end{tabular}

4.2 What is the biggest challenge for students if they would migrate in the future?

Students rank first the job interview as their biggest challenge. In second place they rank their visa interview. After those, they evaluate moving away from home, job-hunting, communication, not knowing anyone in their destination country, food, knowledge of laws and regulations, discrimination and last learning a new language (Table 4).

Table 4: Migration challenges

\begin{tabular}{|c|c|c|c|c|}
\hline & $\mathbf{N}$ & Mean & SD & SE \\
\hline Knowledge of laws and regulations in the destination country & 145.0 & 3.614 & 1.259 & 0.105 \\
\hline Learning a new language & 145.0 & 3.434 & 1.418 & 0.118 \\
\hline Food & 145.0 & 3.731 & 1.192 & 0.099 \\
\hline Communication & 145.0 & 3.890 & 1.113 & 0.092 \\
\hline Moving away from home & 145.0 & 4.000 & 1.155 & 0.096 \\
\hline Finding a job & 145.0 & 3.945 & 1.212 & 0.101 \\
\hline Discrimination & 145.0 & 3.552 & 1.476 & 0.123 \\
\hline Visa interview & 145.0 & 4.103 & 1.039 & 0.086 \\
\hline Job interview & 145.0 & 4.145 & 1.027 & 0.085 \\
\hline Not knowing anyone in the destination country & 145.0 & 3.738 & 1.328 & 0.110 \\
\hline
\end{tabular}




\section{Journal of International Cooperation and Development}

www.richtmann.org/journal

Vol 3, No 1, May 2020

\subsection{H1a: Push factors influencing student decision-making to migrate $(\alpha=0.05)$.}

Push factors such as economic conditions, conflict, unemployment and discrimination influence student decision-making for migrating. Whereas personal safety does not have an important statistical correlation to decision-making for migrating. Table 5 values demonstrate that the correlation between conflict and decision-making to migrate has the largest coefficient, thus is more significant statistically. Analysis shows that four push factors influence decision-making to migrate and one factor does not, which brings to the rejection of the hypothesis. Graphs 5-9 provide a schematic representation.

Table 5: Bayesian Pearson Correlation

\begin{tabular}{llcc}
\hline & & $\mathbf{r}$ & $\mathbf{B F}_{\mathbf{1 0}}$ \\
\hline Economic condition & - Decision-making to migrate & 0.193 & 1.532 \\
Personal safety & - Decision-making to migrate & 0.082 & 0.166 \\
Conflict (feuds) & - Decision-making to migrate & 0.252 & 10.682 \\
Unemployment & - Decision-making to migrate & 0.227 & 4.317 \\
Discrimination & - Decision-making to migrate & 0.245 & 8.152 \\
\hline
\end{tabular}

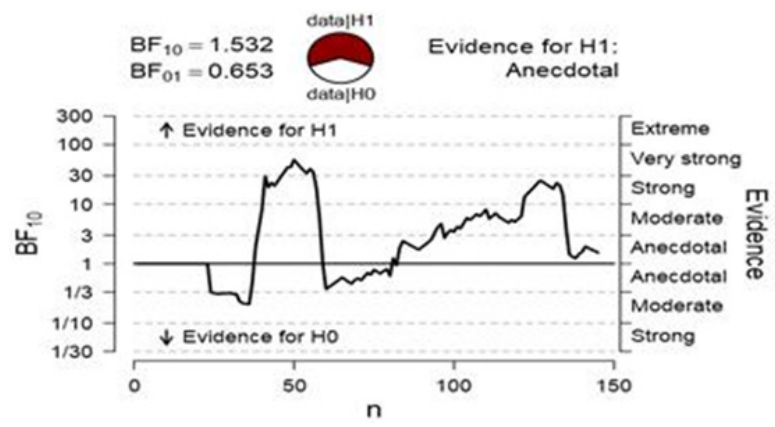

Graph 5: Economic conditions and decision-making to migrate

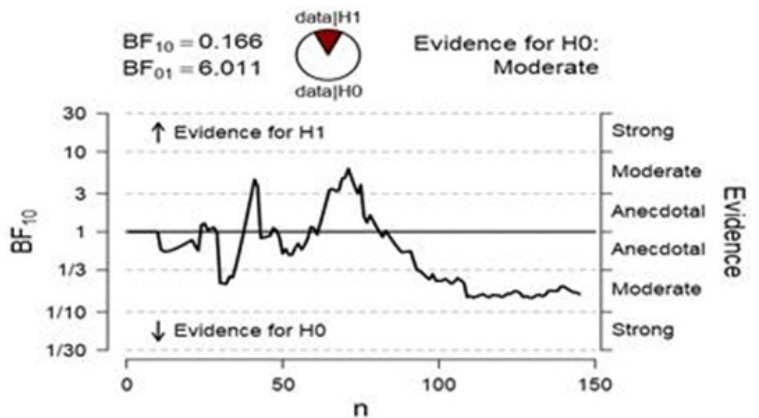

Graph 6: Personal safety and decision-making to migrate 


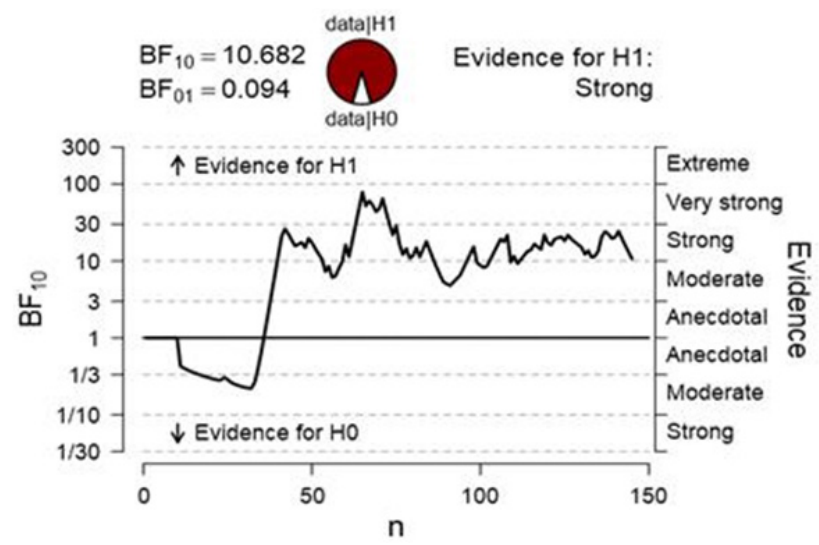

Graph 7: Conflict and decision-making to migrate

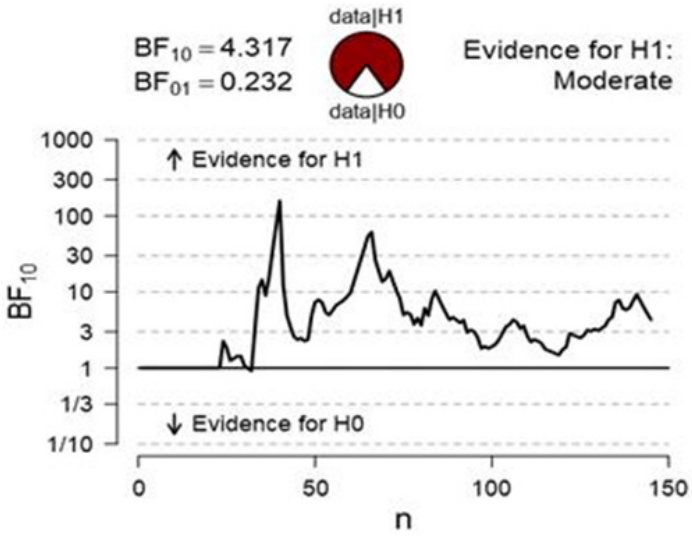

Graph 8: Unemployement and decision-making to migrate

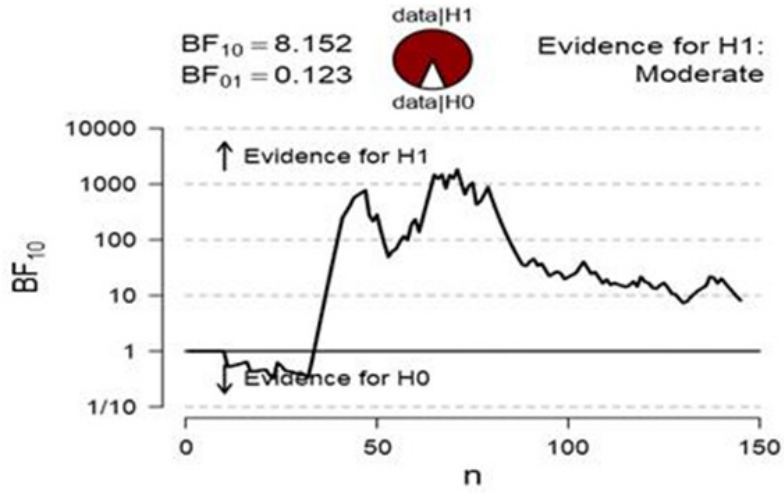

Graph 9: Discrimination and decision-making to migrate 


\section{Journal of International Cooperation and Development \\ www.richtmann.org/journal}

Vol 3, No 1, May 2020

\subsection{H1b: Push factors influencing student perception in migrating ( $\alpha=0.05)$.}

Push factors influence student perception to migrate (Table 6). Between push factors and student perception to migrate there exist a significant statistical correlation. All the correlations between the variables are positive. The strongest correlation exists between personal safety and migration perception. Hypothesis $\mathrm{H} 1 \mathrm{~b}$ is supported with a confidence interval 95\%. Graphs 10-14 show the results of the data analysis.

Table 6: Bayesian Pearson Correlation

\begin{tabular}{llcc}
\hline & & $\mathbf{r}$ & $\mathbf{B F}_{\mathbf{1 0}}$ \\
\hline Economic condition & - Perception of migration & 0.189 & 1.345 \\
Personal safety & - Perception of migration & 0.303 & 90.879 \\
Conflict (feuds) & - Perception of migration & 0.231 & 5.044 \\
Unemployment & - Perception of migration & 0.188 & 1.305 \\
Discrimination & - Perception of migration & 0.230 & 4.804 \\
\hline
\end{tabular}

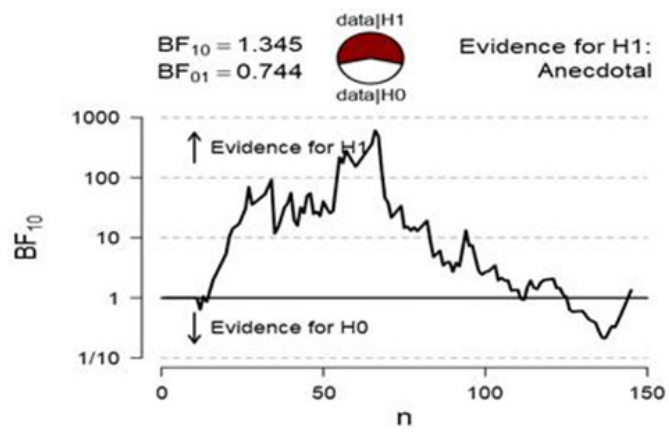

Graph 10: Economic condition and perception of migration

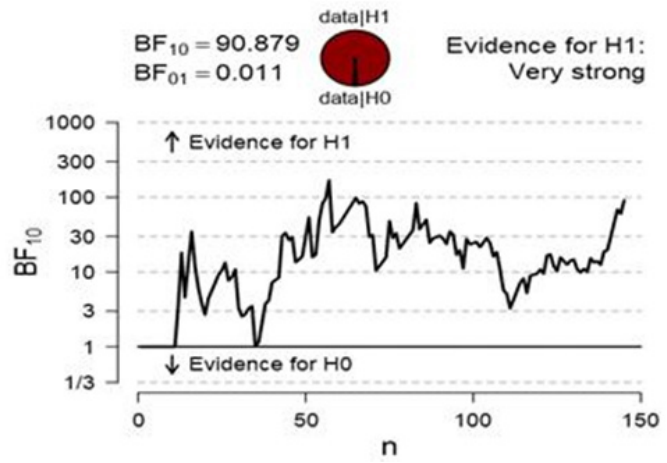

Graph 11: Personal safety and perception of migration 


\section{Journal of International Cooperation and Development \\ www.richtmann.org/journal}

Vol 3, No 1, May 2020

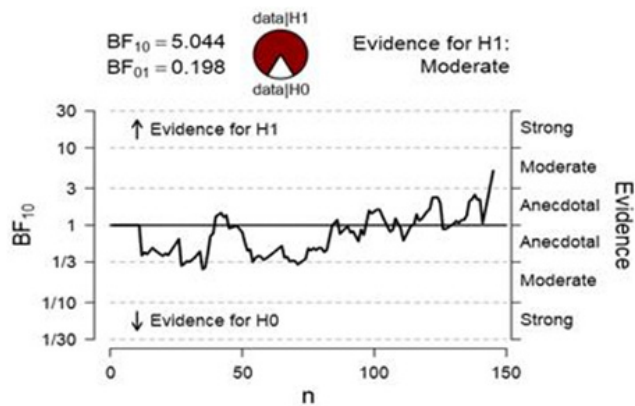

Graph 12: Conflict and perception of migration

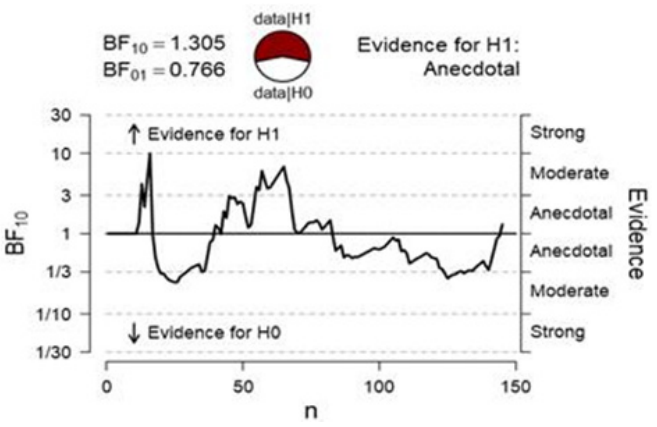

Graph 13: Unemployment and perception of migration

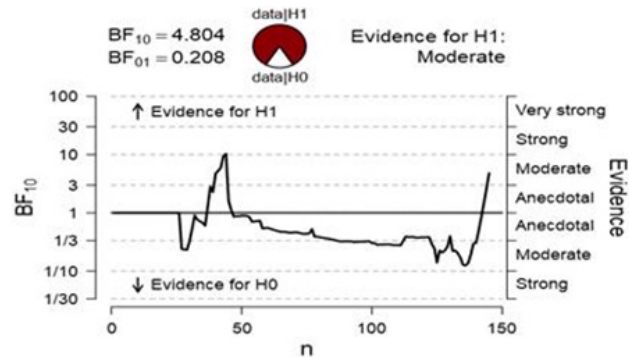

Graph 14: Discrimination and perception of migration

\subsection{H2a: Pull factors influencing student decision-making in migrating ( $\alpha=0.05)$.}

The pull factors in a country, such as the opportunities to advance one's career, improving one's quality of life, the quality of the educational system and marriage influence positively in student decision-making to migrate (Table 7). Moreover, between these factors and the decision-making to migrate there exist significant statistical positive correlations. Other pull factors do not influence student decision-making to migrate. Hypothesis $\mathrm{H} 2 \mathrm{a}$ is refuted. 
Table 7: Bayesian Pearson Correlation

\begin{tabular}{|c|c|c|c|c|}
\hline & & & $\mathbf{r}$ & $\mathrm{BF}_{10}$ \\
\hline Career advancement opportunities & - & Decision-making to migrate & 0.240 & 6.791 \\
\hline Professional development opportunities & - & Decision-making to migrate & 0.112 & 0.252 \\
\hline High salary & - & Decision-making to migrate & 0.030 & 0.110 \\
\hline Exciting work & - & Decision-making to migrate & -0.035 & 0.113 \\
\hline More job opportunities & - & Decision-making to migrate & 0.152 & 0.544 \\
\hline Finding a job in one's study area & - & Decision-making to migrate & 0.051 & 0.125 \\
\hline Improving the quality of life & - & Decision-making to migrate & 0.218 & 3.247 \\
\hline Educational system quality & - & Decision-making to migrate & 0.269 & 20.385 \\
\hline Culture & - & Decision-making to migrate & 0.121 & 0.294 \\
\hline Desire to learn about other countries & - & Decision-making to migrate & -0.045 & 0.120 \\
\hline Desire to travel & - & Decision-making to migrate & -0.109 & 0.241 \\
\hline Family & - & Decision-making to migrate & 0.073 & 0.151 \\
\hline Learning a new language & - & Decision-making to migrate & 0.018 & 0.106 \\
\hline Marriage & - & Decision-making to migrate & 0.223 & 3.782 \\
\hline
\end{tabular}

4.6 H2b: Pull factors influencing student perception in migrating ( $\alpha=0.05)$.

Table 8 values show that pull factors do not influence student perception toward migration. Between pull factors and perception of migration there exist insignificant statistical correlations. Hypothesis $\mathrm{H} 2 \mathrm{~b}$ is also refuted.

Table 8: Bayesian Pearson Correlation

\begin{tabular}{llcc}
\hline & & $\mathbf{r}$ & $\mathbf{B F}_{\mathbf{1 0}}$ \\
\hline Career advancement opportunities & - Perception of migration & 0.043 & 0.118 \\
Professional development opportunities & - Perception of migration & 0.061 & 0.135 \\
High salary & - Perception of migration & 0.041 & 0.117 \\
Exciting work & - Perception of migration & 0.041 & 0.117 \\
More job opportunities & - Perception of migration & 0.098 & 0.207 \\
Finding a job in one's study area & - Perception of migration & 0.079 & 0.162 \\
Improving the quality of life & - Perception of migration & 0.166 & 0.750 \\
Educational system quality & - Perception of migration & 0.145 & 0.468 \\
Culture & - Perception of migration & 0.076 & 0.156 \\
Desire to learn about other countries & - Perception of migration & 0.100 & 0.211 \\
Desire to travel & - Perception of migration & -0.011 & 0.105 \\
Family & - Perception of migration & 0.078 & 0.161 \\
Learning a new language & - Perception of migration & 0.146 & 0.477 \\
Marriage & - Perception of migration & 0.037 & 0.114 \\
\hline
\end{tabular}




\section{Conclusions and Recommendations}

Generally, student attitudes are pro-migration. Migration is viewed by most student respondents as an opportunity. The job and visa interviews are two of the biggest challenges encountered by students.

Push factors influence the perception of students to migrate, at the same time, economic conditions, conflict, unemployment and discrimination influence in student decision-making to migrate. Whereas personal safety does not have a significant statistical correlation with decision-making to migrate.

Pull factors do not influence student perception in migrating. While, career advancement, improvement of the quality of life, and the quality of the educational system influence student decision-making to migrate.

\section{References}

Czaika, M. (2015). Migration and Economic Prospects. Journal of Ethnic and Migration Studies, 41, 58-82. Retrieved February 11, 2018

Czaika, M., \& Vothknecht, M. (2014). Migration and aspirations-are migrants trapped on a hedonic treadmill. IZA Journal of Migration, 3, 1-21. Retrieved February 11, 2018

Ferriss, A. L. (1965). Predicting Graduate Student Migration. Social Forces, 43(3), 310-319. Retrieved February 10, 2018

Filipi, G., Galanxhi, E., Nesturi, M., \& Grazhdani, T. (2013). Migracioni i kthimit dhe ri-integrimi në Shqipëri 2013. Albania: INSTAT \& Organizata Ndërkombëtare për Migracionin.

Gibson, J., \& David, M. (2011). The Microeconomic Determinants of Emigration and Return Migration of the Best and Brightest: Evidence from the Pacific. Journal of Development Economics, 95(1), 18-29. Retrieved February 8, 2018

Hawthorne, L. (2010). How Valuable is "Two-Step Migration"? Labor Market Outcomes for International Student Migrants to Australia. Asian and Pacific Migration Journal, 19(1), 5-37. Retrieved February 9, 2018

Hazen, H., \& C. Alberts, H. (2006). Visitors or Immigrants? International Students in the United States. Population, Space and Place, 12, 201 - 216. Retrieved February 11, 2018

Kerri, J. (1976). "Push" and "Pull" Factors: Reasons for Migration as a Factor in Amerindian Urban Adjustment. Human Organization, 35(2), 215-220. Retrieved February 11, 2018

Kumpikaite, V., \& Zickute, I. (2012). Synergy of Migration Theories: Theoretical Insights. Inzinerine Ekonomika-Engineering Economics, 23(4), 387-394. Retrieved February 9, 2018

McGill, J. (2013). International Student Migration: Outcomes and Implications. Journal of International Students, 3(2), 167-181. Retrieved February 10, 2018

Polgreen, L., \& Simpson, N. B. (2011). Happiness and international migration. Journal of Happiness Studies, 12, 819-840. Retrieved February 10, 2018

Ramirez, A. M., \& Kumpikaite, V. (2013). Economics reason of migration from point of view of students. 2nd World Conference On Business, Economics And Management (pp. 522-526). Turkey: ELSEVIER. 


\section{Journal of International Cooperation and Development}

www.richtmann.org/journal

Vol 3, No 1, May 2020

Saxenian, A. (2005). Brain Circulation and Capitalist Dynamics: Chinese Chipmaking and the Silicon Valley-Hsinchu-Shanghai Triangle. In V. Nee, \& R. Swedberg (Eds.), The Economic Sociology of Capitalism. Princeton NJ: Princeton University Press.

Semiv, L., \& Semiv, R. (2010). Regional peculiarities of educational migration in Ukraineoman. Economics \& Sociology, 3(1), 123-132. Retrieved February 9, 2018

Tupa, M., \& Strunz, H. (2013). Social and Economic Effects of International Migration. Economics \& Management, 18, 509-520. Retrieved February 10, 2018

Žičkutè, I., \& Kumpikaite, V. (2015). Theoretical insights on the migration process from economic. 20th International Scientific Conference Economics and Management (pp. 873-878). Lithuania: ELSEVIER. 